\title{
Home ranges of released West Indian manatees Trichechus manatus in Brazil
}

\author{
Sebastião Silva dos Santos, Iara dos Santos Medeiros \\ Vanessa Araujo Rebelo, Allan Oliveira Barreto Carvalho \\ Jean Paul Dubut, José Eduardo Mantovani \\ Raphael Dantas Círiaco, Ryan Emerson Gomes dos Santos \\ Miriam Marmontel, Iran Campello Normande \\ Thalma Maria Grisi Velôso and Joño Carlos Gomes Borges
}

\begin{abstract}
The distribution of the Vulnerable West Indian manatee Trichechus manatus is influenced by physical and environmental factors such as water salinity, temperature and depth, freshwater supply and the availability of food resources. In Brazil, information on the habitat use of this species is insufficient for effective conservation. Here, we monitored manatees that had been found stranded as calves, rehabilitated in captivity and subsequently released, to identify their home ranges and examine their adaptation to life in the wild. The study, which involved monitoring six manatees using satellite and VHF telemetry systems, was conducted during 2016-2019 in the states of Paraíba, Sergipe and Bahia in north-eastern Brazil. Home range size of individuals was $2.56-42.07 \mathrm{~km}^{2}$ and all fidelity sites (areas used most frequently) were within protected areas. The longest distance travelled from the coastline upriver was $14.24 \mathrm{~km}$ and the longest distance offshore was $0.93 \mathrm{~km}$. There were no significant differences in home range data between the dry and rainy seasons, but there was significant difference between the sexes, with males travelling across larger areas than females. All but one of the six individuals met the majority of indicators established in the Brazilian Manatee
\end{abstract}

Sebastiāo Silva dos Santos* (DD orcid.org/0000-0003-0194-2975), Iara dos Santos Medeiros* (ㄷ) orcid.org/0000-0002-7467-5970), Vanessa Araujo Rebelo* (10) orcid.org/0000-0001-7139-7189) and Allan Oliveira BarReto CARVAlHo (잉 orcid.org/0000-0002-8274-2416) Aquatic Mammals Foundation, Recife, Brazil

Jean Paul Dubut, José Eduardo Mantovani (10 orcid.org/0000-0003-17193833), Raphael Dantas Círiaco (당 orcid.org/0000-0002-8047-4542) and Ryan EMERSON Gomes dos SANTos (D orcid.org/0000-0002-4214-5457) Nortronic, Natal, Brazil

Miriam Marmontel (ํ) orcid.org/0000-0003-3747-9548) Mamirauá Sustainable Development Institute, Tefé, Brazil

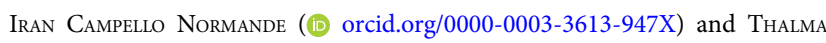
Maria Grisi Velôso Chico Mendes Institute for Biodiversity Conservation, Maceió, Brazil

JoÃo CARLOS GOMES BoRGES* (Corresponding author, (1) orcid.org/0000-0002-00336781, jcgborges@hotmail.com) Aquatic Mammals Foundation, Pernambuco, 52.051-305, Brazil

${ }^{*}$ Also at: Graduate Program in Ecology and Environmental Monitoring, Federal University of Paraíba, Rio Tinto, Brazil

Received 18 September 2020. Revision requested 22 January 2021.

Accepted 26 May 2021. First published online 31 January 2022.
Reintroduction Protocol, and thus were considered to have successfully adapted to the wild. Our study provides information on patterns of habitat use and areas intensely used by manatees, which can assist protected area managers in defining priority areas for manatee conservation in Brazil.

Keywords Brazil, distribution, Endangered, fidelity site, habitat use, protected area, sirenian, telemetry

\section{Introduction}

The West Indian manatee Trichechus manatus is cate1 gorized as Endangered on the Brazilian Red List (ICMBio, 2018) and as Vulnerable on the IUCN Red List (Deutsch et al., 2008). Along the Brazilian coast, manatee populations are patchily distributed from Amapá to Alagoas (Luna et al., 2008; de Lima et al., 2011) and there is evidence of released animals using the coasts of Sergipe and Bahia states (Deutsch et al., 2008). The distribution of manatees is influenced by physiological (nutrition and metabolism; St Aubin \& Lounsbury, 1990) and environmental factors (water salinity, temperature and depth, and availability of food resources; Lefebvre et al., 2001), freshwater supply (Favero et al., 2020) and anthropogenic habitat modifications (Deutsch et al., 2008). Manatees prefer naturally sheltered areas such as coves, bays and estuaries and are sensitive to disturbance caused by the construction and operation of cities, ports, marinas, shipyards, salt works, shrimp farms and other anthropogenic structures and activities in these areas (Aquasis, 2016). Such habitat modifications are associated with an increase of manatee calf stranding events along the north-eastern Brazilian coast (Parente et al., 2004; Meirelles, 2008; Medeiros et al., 2021). Without access to undisturbed estuaries, females give birth in open water, where newborns may become separated from mothers and stranded on the coast (de Lima et al., 2011). Stranded calves found alive are transferred to one of three rehabilitation facilities in north-eastern Brazil (Meirelles, 2008). After an initial health assessment, they are kept in individual pools for a quarantine period of c. 2 months, and 
later moved to larger pools with other calves. They are fed soya milk formula, algae and seagrass. At 1 year of age they are moved to an oceanarium and offered a diet of seagrass and algae supplemented with vegetables (carrots and lettuce) and vitamins (Normande et al., 2015).

After rehabilitation and following the Brazilian Manatee Reintroduction Protocol (de Lima et al., 2007), the animals are transferred to enclosures in the Mamanguape River estuary or Tatuamunha River, within two marine protected areas (Mamanguape River Environmental Protection Area in Paraíba and Environmental Protection Area Costa dos Corais in Alagoas, respectively). Manatees spend 15 days-12 months in these areas, adapting in captivity (i.e. enclosures within estuaries) to local environmental conditions (Normande et al., 2015).

The Manatee Reintroduction Programme was created in 1994 with the purpose of re-establishing the original geographical distribution of the manatee in Brazil (de Lima et al., 2007). As a result of this initiative, the number of rescued and rehabilitated manatees increased during 1994-2020, with a total of 48 manatees released (de Lima et al., 2012; Normande et al., 2016, 2019). These efforts to rehabilitate and release stranded manatees have facilitated the reconnection of isolated populations and the restocking of areas where manatees historically occurred (Normande et al., 2016).

Upon release, manatees tend to use estuarial and coastal areas (Normande et al., 2016). Based on their movement patterns, the area used by released individuals, expanding over time from their respective release sites, is conceptually defined as their home range, and the extreme geographical positions reached during movements constitute the limits of their territories (de Lima et al., 2012).

Data on habitat use and movement patterns, gathered as part of release and reintroduction programmes, provide insights into movements, ecological aspects and impacts of human activities, which can facilitate the conservation of species and habitats (Normande et al., 2016). Considering the ecological importance of manatees (Aquasis, 2016), their vulnerability and the threats to which they are exposed (de Lima et al., 2011), further studies on their distribution and home ranges are warranted. Mapping habitat use patterns, the most used resources, home ranges and the routes and corridors used between these areas is important for manatee conservation. This information can help identify priority areas for habitat protection and assist in mitigation of anthropogenic impacts. It may also help improve manatee rehabilitation strategies based on the influence of captive management on post-release behaviour. The aim of our study was to identify the home ranges of released manatees in Brazil and evaluate their adaptation to life in the wild.

\section{Study area}

We tracked the movements of rescued, rehabilitated and released manatees in the north-eastern Brazilian states of
Paraíba, Sergipe and Bahia (Fig. 1). In Paraíba, manatees mainly use the estuary of the Mamanguape River in the municipality of Rio Tinto and the estuary of the Paraíba do Norte River, between the municipalities of Cabedelo and Lucena, where the Cabedelo Port is located, which has considerable motorboat traffic. In Sergipe and Bahia, the study areas were in the estuary of the Vaza Barris River and the Piauí-Fundo-Real estuarine complex. The Piauí River is 132 $\mathrm{km}$ long and flows into the Atlantic ocean between the municipalities of Estância (Sergipe) and Jandaíra (Bahia). The climate in the area is characterized by a dry (SeptemberFebruary; mean monthly rainfall $62 \mathrm{~mm}$ ) and rainy (MarchAugust; mean monthly rainfall $262 \mathrm{~mm}$ ) season.

\section{Methods}

\section{Manatee tracking}

Six manatees (named Astro, Mel, Puã, Tita, Yara and Zelinha) that had been released during 1994-2012 (de Lima et al., 2012; Normande et al., 2016) were monitored by the Aquatic Mammal Foundation during 2016-2019 (Table 1). The tracking apparatus consisted of a belt attached to each animal's caudal peduncle, a tether (flexible nylon rod attaching the belt to the transmitter housing; de Lima et al., 2007) and a radio transmitter (Nortronic/Aquatic Mammals Foundation, Natal, Brazil). The transmitting assemblage consisted of a GPS device to record geographical coordinates, a satellite transmitter programmed to send signals every 3 hours through the Globalstar network (Globalstar, Covington, USA), and a conventional VHF transmitter operating continuously to transmit locations in real-time (Borges et al., 2020).

An experienced team periodically captured the released manatees during periods of low tide for clinical management and deployment of the satellite tags. The animals were captured with a custom-made $150-\mathrm{m}$ long net deployed in a circle from a boat. Prior to fitting the tracking equipment, they were evaluated clinically, and biological samples and biometrics were collected (White \& Francis-Floyd, 1990). Captures for clinical management occurred every 6 months or according to the needs of individual animals (de Lima et al., 2007). When lost transmitters needed to be replaced or adjustments made to the belts because of changes in the animal's weight, this was done by diving or by recapturing the animal.

\section{Data collection}

We received information on the location of individuals (date, time and geographical coordinates) from the satellite system on a daily basis, and downloaded the data through the Globalstar system via e-mail, a smartphone application or the system's digital platform. We used the VHF system to 

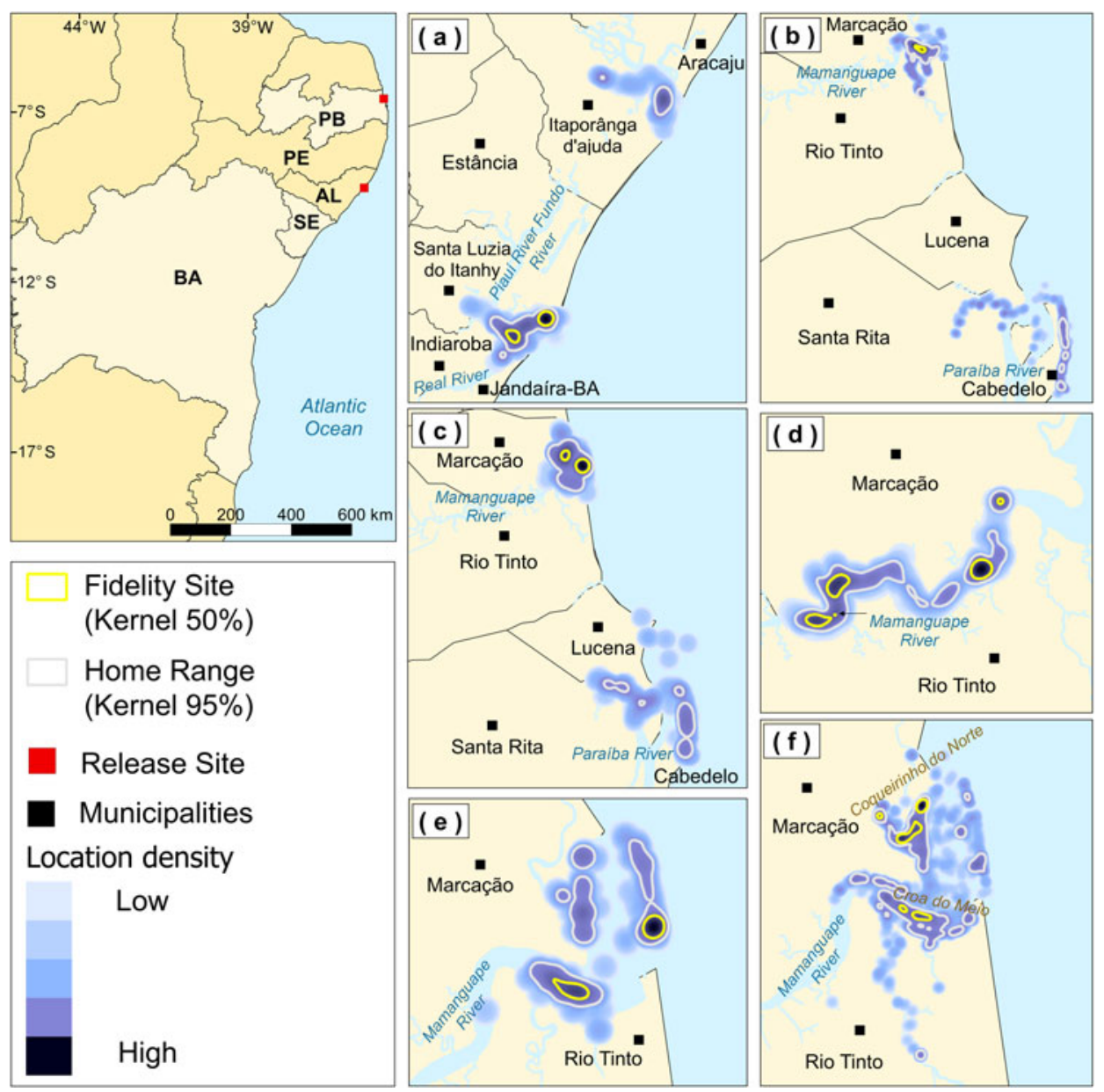

FIG. 1 The study area in north-eastern Brazil (AL, Alagoas; BA, Bahia; PB, Paraíba; PE, Pernambuco; SE, Sergipe), where six released West Indian manatees Trichechus manatus were monitored during 20162019. (a) Astro's home range in the Piauí/Fundo/Real rivers estuarine complex and at the mouth of the Vaza Barris River, (b) Mel's and (c) Puã's home ranges at the mouths of the Mamanguape and Paraíba Rivers, (d) Tita's home range in the Mamanguape River, (e) Yara's and (f) Zelinha's home ranges at the mouth of the Mamanguape River. visually locate individuals during fieldwork, to collect data on behaviour, areas used and interactions with people. Field surveys were conducted daily, with observers travelling on foot, by car or in small motorboats. Data collected included geographical location, name of the site, identification of the individual, transmitter number, water depth, distance to high tide line, weather and tidal conditions, visibility, behaviour of the individual, presence of people and type of any interaction, and composition of the research team. Each hour of monitoring included 15 minutes of behaviour observation.

Locations were visualized using QGIS 3.10 (QGIS Development Team, 2019), resulting in the identification of the main areas used by each individual monitored, in the dry and rainy seasons. We used the Home Range tool in QGIS to calculate the areas of use, defining an animal's home range as the area containing $95 \%$ of the locations obtained; this excludes sporadic displacements that are not considered as part of the individual's home range (Normande et al., 2016). We had sufficient data to calculate home ranges in the dry and rainy seasons for four individuals: Astro, Mel, Puã and Zelinha.

We used a Kruskal-Wallis test to examine any differences in the home range (response variable) among individuals (Astro, Mel, Puã and Zelinha; categorical variable), and Mann-Whitney tests to examine any differences between seasons (dry and rainy) and sexes (male and female). When there were significant differences, we used Dunn's post hoc test to identify heterogeneous groups. All tests were performed in $R$ 3.5.o (R Core Team, 2018).

We used the kernel estimator to calculate the home range (95\% kernel) of each animal monitored (Normande et al., 2015). Areas with greater concentration of coordinates were classified as fidelity sites (50\% kernel; CastelblancoMartínez et al., 2012); the number of coordinates that comprised these sites was $50 \%$ of all locations recorded for each manatee (Normande et al., 2015).

\section{Assessment of adaptation of released manatees}

We evaluated the adaptation of released manatees to the wild considering a number of criteria for success: capacity to find food sources and feed in the short term, remaining in adequate habitat, use of freshwater sources, body measurements appropriate for the animal's age, no evidence of disease or parasites, interaction with native and/or other released manatees, evidence of reproductive behaviour, little 


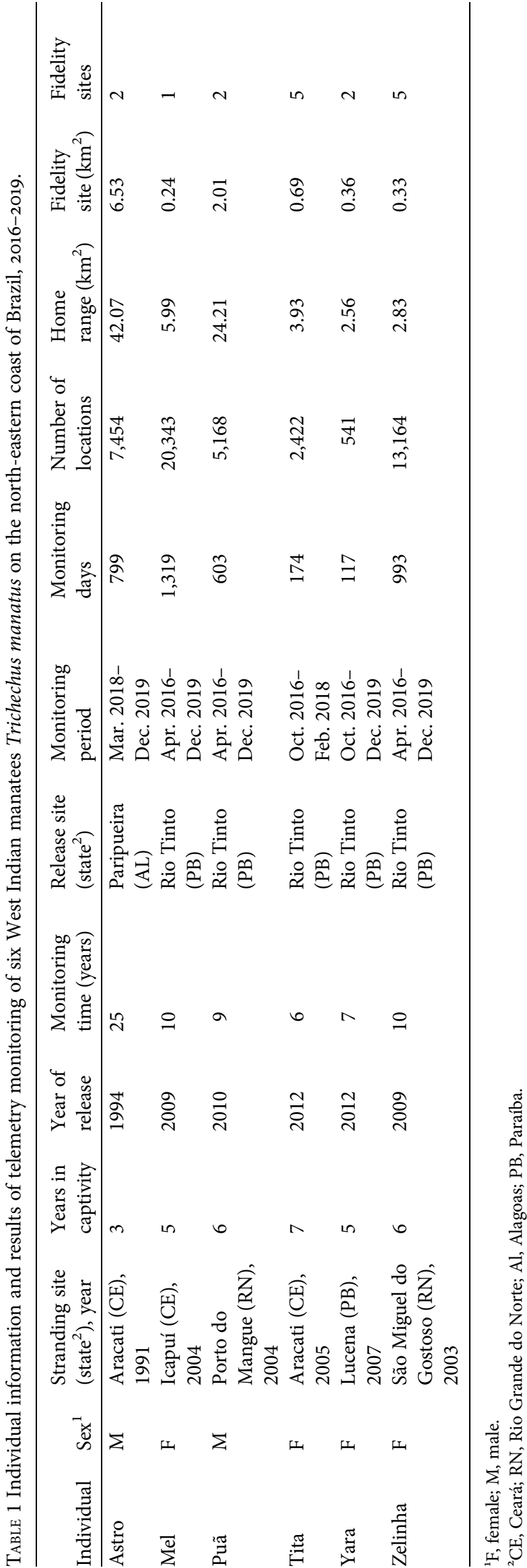

affinity with people or gradual loss of any such affinity, and (for females) gestation in the medium and long term (5-10 years; de Lima et al., 2007).

In addition to these criteria, manatees surviving for 1 year after release, using adequate habitats, not requiring repeated rescuing, and exhibiting good physical condition were considered successful releases (Normande et al., 2015; Adimey et al., 2016).

\section{Results}

The combined total number of monitoring days for all manatees was 4,005. Astro was the only individual to use areas in the states of Sergipe and Bahia, with a home range of $42.07 \mathrm{~km}^{2}$ and two fidelity sites (Fig. 1a). In the Vaza Barris River, he travelled $14.24 \mathrm{~km}$ upstream and $0.42 \mathrm{~km}$ from the coast. His main area of use was the estuarine complex of the Piauí/Fundo/Real Rivers, where he travelled $12.56 \mathrm{~km}$ upstream (but used these areas with less intensity) and ranged $0.93 \mathrm{~km}$ from the coast.

Mel and Puã were the only animals monitored in the state of Paraíba that visited areas beyond the limits of the Mamanguape River estuary, with a larger home range than others in the state. Mel had a home range of $5.99 \mathrm{~km}^{2}$, mainly encompassing the estuary of the Mamanguape River, where her sole fidelity site was located. She travelled up to $3.59 \mathrm{~km}$ upstream and $0.55 \mathrm{~km}$ from the coast. She also travelled c. $28 \mathrm{~km}$ south, to the beaches of Cabedelo, making use of coastal areas and the Paraíba River estuary, where she moved $7.71 \mathrm{~km}$ upstream and $0.57 \mathrm{~km}$ from the coast (Fig. 1b).

Puã's home range was $24.21 \mathrm{~km}^{2}$, encompassing the estuaries of the Mamanguape and Paraíba Rivers. This individual mainly used the Mamanguape River estuary, where two fidelity sites were identified. He travelled $3.08 \mathrm{~km}$ upstream and $0.52 \mathrm{~km}$ from the coast. In the Paraíba River, he travelled $7.06 \mathrm{~km}$ upstream and $0.68 \mathrm{~km}$ offshore (Fig. 1c).

Tita, Yara and Zelinha used areas within the estuary of the Mamanguape River, in Paraíba. Tita's home range differed from that of the others, using only upstream areas of the Mamanguape River and reaching $10.17 \mathrm{~km}$ upriver. Tita was never recorded near the mouth of the river. Her home range was $3.93 \mathrm{~km}^{2}$, with five fidelity sites (Fig. 1d).

Yara's $2.56 \mathrm{~km}^{2}$ home range encompassed two fidelity sites. She mostly used the area near the reefs, including one fidelity site. She also often used Croa do Meio and the mouth of the Camurupim River, and travelled $3.56 \mathrm{~km}$ upriver and up to $0.69 \mathrm{~km}$ from the coast (Fig. 1e). Both of her fidelity sites were located in areas regularly used by manatees for feeding. Yara also used two tributaries near the mouth of the Mamanguape River, where salinity is low: the Sinibú and the Caracabú, on the left and right bank of the Mamanguape, respectively (her captive adaptation location was at the Caracabú tributary). 
Zelinha's home range, including five fidelity sites, was $2.83 \mathrm{~km}^{2}$. This manatee mainly visited Coqueirinho Beach to the north, the mouth of the Camurupim River, and Croa do Meio, reaching $4.85 \mathrm{~km}$ upstream and $0.54 \mathrm{~km}$ from the coast (Fig. if).

Males Astro and Puã had the largest home ranges, and females Tita and Zelinha had the largest number of fidelity sites. All fidelity sites were within protected areas (in estuaries, bays or upstream on the river).

Integrating data from all manatees monitored, we mapped the main areas used by the animals. In Paraíba, they mainly used two rivers: Mamanguape and Paraíba. In the estuary of the Mamanguape River, the manatees travelled up to c. $10 \mathrm{~km}$ upstream from the mouth. Two of the five animals monitored in Paraíba (Mel and Puã) made trips from the Mamanguape River to the beaches of the Cabedelo municipality, c. $28 \mathrm{~km}$ away. There, the animals used the estuary of the Paraíba River and one of its tributaries (Guia River), reaching up to $7.71 \mathrm{~km}$ upstream, and frequently used the coastal areas. Reefs, which reduce the effects of waves and currents (Barbier et al., 2011), are found at both locations. The animals ventured up to $0.68 \mathrm{~km}$ offshore, but did not use the open sea beyond these reef formations. In Sergipe and Bahia, Astro mainly used the estuaries of the Vaza Barris River in Sergipe and the Piauí/Fundo/Real estuarine complex, on the border between the two states, travelling c. $37.23 \mathrm{~km}$ between these two areas.

There were no significant differences between the dry and rainy season ranges of four manatees (Astro, Mel, Puã and Zelinha; Mann-Whitney: $U=67 ; \mathrm{P}=0.57$ ) throughout the monitoring period (Table 2). There was, however, a significant difference in the home range size of individual manatees (Kruskal-Wallis: $H_{(3)}=9.86 ; \mathrm{P}=0.01$ ), and males had significantly larger home ranges than females (MannWhitney: $U=19 ; \mathrm{P}=0.01$ ).

During the study period, some individuals exhibited symptoms of illness or injury (Table 3). Three (Mel, Puã and Zelinha) had a mild nasal secretion that did not require medicinal intervention and resolved before the end of the study period. Puã also exhibited gastrointestinal problems, which regressed spontaneously. Astro, Mel and Puã had injuries caused by trauma (some sustained in collisions with motorized watercraft) and were submitted to an individual evaluation and therapeutic protocol. Tita, who had a similar haematological pattern as the other animals, was found dead at Boa Vista Port in February 2018 in a tributary of the Mamanguape River. The necropsy revealed faecaloma, pulmonary embolism and cardiopulmonary arrest.

Manatees used freshwater sources 1-11 times per month in the dry season and 1-12 times per month in the rainy season. There were no significant differences among individuals (Kruskal-Wallis: $H_{(2)}=1.201 ; \mathrm{P}=0.54$ ) or between seasons (Mann-Whitney: $U=718.5 ; \mathrm{P}=0.06$; Table 4 ).

\section{Discussion}

The manatees monitored in this study used estuarine areas more intensely than the open sea. The same pattern was reported for 20 manatees released along the coast of northeastern Brazil (Normande et al., 2016), which used the estuarine environment with greatest intensity, followed by mixed habitats and the marine environment, suggesting that this preference may be linked to sources of freshwater in estuaries.

The use of upstream areas of rivers varied by individual, with some travelling up to $14 \mathrm{~km}$ upstream. These movements are believed to be motivated by the search for sources of freshwater, as reported in previous studies (Ross, 2007; Castelblanco-Martínez et al., 2012; Normande et al., 2016).

Astro, Mel and Puã travelled the longest distances, and these travels were always between two estuaries. Some of the individuals we monitored had been studied previously. De Lima \& de Passavante (2013) reported three fidelity sites used by Astro during 1994-2004: Maré Mansa beach in Alagoas during the early post-release period, and the estuaries of the Vaza Barris River and Piauí/Real/Fundo complex, both in Sergipe. Sixteen years later (our study), he still used the estuary of the Vaza Barris River, but his fidelity sites were in the Piauí/Real/Fundo estuarine complex.

Normande et al. (2016) analysed the home range of four individuals monitored in this study (Mel, Puã, Tita and Zelinha) during November 2008-June 2013. Compared to this earlier period, the home ranges of Mel, Tita and Zelinha decreased by $0.42,2.09$ and $3.82 \mathrm{~km}^{2}$, respectively, whereas Puã's home range increased by $2.02 \mathrm{~km}^{2}$. The reductions in home range size may indicate that the animals identified the best feeding sites after 2013 and subsequently did not need to travel as far in search of food. Tita, Yara and Zelinha have remained within the limits of the Mamanguape River estuary since their release. De Lima et al. (2012) observed similar behaviour, with released manatees staying near their release site.

We did not record any of the individuals studied in areas beyond the reef barrier, but it is believed that manatees use these areas as corridors for movements between estuaries (de Lima et al., 2012; Normande et al., 2016). Paludo \& Langguth (2002) reported similar findings from a study of native manatees in the state of Rio Grande do Norte. The fact that there are few GPS locations recorded from these areas may also be linked to water depth and animal movements, as manatees use open waters for fast movements between estuaries, during which the transmitter remains mostly submerged and thus no signal is transmitted (Edwards et al., 2016).

The fidelity sites identified in this study were in sheltered areas with low incidence of waves and currents (estuaries, bays and areas protected by reefs), which demonstrates the importance of such areas to manatees. Similar findings 
TABLE 2 Home range size ( $95 \%$ kernel, $\mathrm{km}^{2}$ ) of four West Indian manatees monitored with telemetry along the north-eastern coast of Brazil, by season (dry or rainy), during 2016-2019.

\begin{tabular}{|c|c|c|c|c|c|c|c|c|}
\hline \multirow[b]{2}{*}{ Individual } & \multicolumn{2}{|l|}{2016} & \multicolumn{2}{|l|}{2017} & \multicolumn{2}{|l|}{2018} & \multicolumn{2}{|l|}{2019} \\
\hline & Dry & Rainy & Dry & Rainy & Dry & Rainy & Dry & Rainy \\
\hline Astro & & & & & 86.679 & 8.127 & 55.137 & 9.025 \\
\hline Mel & 0.552 & 1.001 & 0.392 & 0.851 & 0.363 & 0.528 & 64.593 & 20.764 \\
\hline Puã & & & 73.412 & 1.503 & 2.485 & 35.152 & 38.827 & 63.138 \\
\hline Zelinha & & 0.216 & 0.547 & 2.969 & 2.175 & 2.431 & 3.146 & 2.461 \\
\hline
\end{tabular}

TABLE 3 Total body length, weight (at last evaluation) and clinical data of six released West Indian manatees on the north-eastern coast of Brazil, 2016-2019.

\begin{tabular}{lllllll}
\hline Individual & Length $(\mathrm{cm})$ & Weight $(\mathrm{kg})$ & $\begin{array}{l}\text { Clinical respiratory } \\
\text { symptoms }\end{array}$ & $\begin{array}{l}\text { Clinical gastrointestinal } \\
\text { symptoms }\end{array}$ & Traumata & Treatment \\
\hline Astro & 309 & 457.7 & No & No & Yes & Yes \\
Mel & 255 & 334.0 & Yes & No & Yes & Yes \\
Puã & 278 & 398.2 & Yes & Yes & No & No \\
Tita & 218 & 204.2 & No & No & No & No \\
Yara & 255 & 251.4 & No & No & No & Yes \\
Zelinha & 251 & 316.8 & Yes & & & \\
\hline
\end{tabular}

TABLE 4 Monthly frequency of use of freshwater sources by three West Indian manatees monitored with telemetry along the northeastern coast of Brazil, 2016-2019.

\begin{tabular}{lllllllll}
\hline & \multicolumn{2}{l}{ Dry season } & & \multicolumn{3}{l}{ Rainy season } \\
\cline { 2 - 4 } \cline { 7 - 8 } Individual & Min & Max & Mean & & Min & Max & Mean \\
\hline Mel & 1 & 11 & 4.4 & & 1 & 8 & 3.1 \\
Puã & 2 & 8 & 4.4 & & 2 & 10 & 4.6 \\
Zelinha & 2 & 11 & 5.7 & & 1 & 12 & 3.8 \\
\hline
\end{tabular}

have been reported for north-eastern Brazil (de Lima \& de Passavante, 2013; Normande et al., 2016) and Mexico (Castelblanco-Martínez et al., 2012). In Paraíba, all fidelity sites were located in the estuary of the Mamanguape River, and three individuals were not recorded in any other estuaries. This shows how important this estuary is for the species in Brazil. Animals with small home ranges and few fidelity sites may become vulnerable to the degradation of these environments (de Lima \& de Passavante, 2013). It is therefore important to release manatees in protected areas (de Lima et al., 2007), where suitable habitats are protected.

Tita's fidelity sites were located further upstream than those of other individuals, reaching $10 \mathrm{~km}$ upriver. No other monitored individuals were observed close to these upstream sites, but fishermen interviewed by da Silva et al. (2011) reported the occurrence of manatees in the area.

The differences in home ranges between seasons were non-significant in this study, but de Lima \& de Passavante (2013) described seasonal patterns of manatee movements in north-eastern Brazil, with larger home ranges and more movement in the dry season. According to de Lima et al. (2012), these movements, occurring mainly at the end of the rainy season and during the dry season, are exploratory. In contrast, Normande et al. (2016) found no clear seasonal pattern when analysing long-distance movements of manatees.

In studies of Florida manatees, seasonal movements were often associated with changes in water temperature (Deutsch et al., 2003; Flamm et al., 2005). In Brazil, waters are warm, with a mean annual temperature of $>24^{\circ} \mathrm{C}$ (da Silva et al., 2011; de Lima et al., 2011). In regions where temperature is not a motivating factor, seasonality may be motivated by the availability of freshwater and adequate habitats in the dry and rainy seasons (Reynolds et al., 2009). Availability of food sources is considered a determinant factor for habitat use by manatees in Brazil (Paludo \& Langguth, 2002), but the triggers of seasonal movements are still not well understood. De Lima et al. (2012) suggested that food may not be the main motivating factor because these movements always start at a fidelity site where conditions are favourable for the animals. In a study of native manatees in the state of Piauí, areas of use were more strongly correlated with sources of freshwater than any other resource, suggesting that the distribution of manatees is driven by the proximity of freshwater (Favero et al., 2020).

In our study, male manatees had larger home ranges than females, as in Mexico and Florida (Flamm et al., 2005; Castelblanco-Martínez et al., 2012). However, Normande et al. (2016) found no differences in home 
range size between males and females in Brazil. Flamm et al. (2005) described manatee movement patterns in Florida for solitary males, solitary females and females with calves; they found that males had significantly higher movement rates than both categories of females. The search for receptive females has been suggested as a probable reason for the greater distances travelled by males (Deutsch et al., 2003), and this may maximize their individual reproductive success (Castelblanco-Martínez et al., 2012).

Astro and Tita were the only individuals not recorded to interact with other native or released manatees. Astro used the coasts of Sergipe and Bahia, where manatees occurred historically. Considering the presence of other manatees in the estuary of the Mamanguape River (da Silva et al., 2011), it is likely that Tita did interact with other manatees, but we did not record this.

All animals evaluated adapted to life in the wild and were considered successful releases, according to the Brazilian Manatee Reintroduction Protocol (de Lima et al., 2007; Normande et al., 2015; Adimey et al., 2016). Success in the rescue and release process requires long-term, continuous monitoring with the support of veterinary interventions whenever necessary, use of monitoring systems with accurate transmission of geographical coordinates, and releasing animals up to 5 years of age (Normande et al., 2015). Additionally, it is important to engage local communities, especially fishers, in the participatory monitoring of animals, both in reporting manatee occurrence and recovering lost transmitters.

Tita, Yara and Zelinha remained throughout the entire monitoring period in the estuary of the Mamanguape River, where they re-adaptated in captivity (enclosures inside estuaries), demonstrating the importance of this step to post-release success. According to de Lima \& de Passavante (2013), a site can be considered to have fulfilled its function as a temporary adaptation area when the animals use the surrounding region for a time after their release; when released manatees immediately move away from the site, it means it had no influence on the adaptation process.

In Brazil, one of the goals of the reintroduction programme is to restock areas of historical occurrence (Normande et al., 2016). This was achieved by Astro, making the states of Sergipe and Bahia the current southernmost distribution limit of the species.

The identification of spatio-temporal patterns of habitat use by manatees, the mapping of intensely used areas and the evaluation of the adaptation of released animals to life in the wild provide important data that can assist protected area managers in defining priority areas for conservation. The information will contribute to the Management Plan for the Mamanguape River Environmental Protection Area through regulation of coastal development and activities such as fishing, boat traffic and tourist activities. The data, which were shared with the relevant government institutions, will also contribute to the National Action Plan for the Conservation of Manatees (ICMBio, 2011).

Acknowledgements We thank the Aquatic Mammal Foundation for logistical and technical support; the Graduate Program in Ecology and Environmental Monitoring and the Cartography and Geoprocessing Lab-UFPB for scientific and academic support; Environmental Protection Areas of Costa do Corais and the Mamanguape River, the National Research and Conservation Center for Marine Biodiversity of the Northeast/ICMBio for support with field work; Nortronic for technical assistance with transmitters; James Reid, Susan Butler, Robert Bonde (U.S. Geological Survey/ Sirenia Project) for their support and cooperation; the Long Live the Manatee project of the Aquatic Mammal Foundation, the Petrobras Socioenvironmental Program and the Manatee Conservation Program of the Aquatic Mammal Foundation in partnership with the Boticário Group Foundation for the Conservation of Nature (Fundação Grupo Boticário de Conservação à Natureza) for funding; and the anonymous reviewers for their comments.

Author contributions Study design: SSdS, VAR, MM, JCGB; contribution to the manufacture of the tagging accessories: SSdS, ICN; development of the radio transmitters and assistance in their use: JPD, JEM, RDC, REGdS, JCGB; fieldwork: SSdS, VAR, AOBC, IdSM, TMGV; data analysis and writing: SSdS, ICN, IdSM, MM, JCGB; revision: all authors.

\section{Conflicts of interest None.}

Ethical standards This research was carried out under ICMBio/ SISBio (Biodiversity Authorization and Information System) permits $\# 25820$ and \#54205 and otherwise abided by the Oryx guidelines on ethical standards.

\section{References}

Adimey, N.M., Ross, M., Hall, M., Reid, J.P., Barlas, M.E. Diagne, L.W.K. \& Bonde, R.K. (2016) Twenty-six years of post-release monitoring of Florida manatees (Trichechus manatus latirostris): evaluation of a cooperative rehabilitation program. Aquatic Mammals, 42, 376-391.

Aquasis (2016) Peixe-Boi-Marinho: Biologia e Conservação. Bambu Editora e Artes Gráficas Ltda, São Paulo, Brazil.

Barbier, E.B., Hacker, S.D., Kennedy, C., Koch, E.W., Stier, AC. \& Silliman, B.R. (2011) The value of estuarine and coastal ecosystem services. Ecological Monographs, 81, 169-193.

Borges, J.C.G., dos Santos, S.S., Rebelo, V.A., Mantovani, J.E., Círiaco, R.D., Marmontel, M. et al. (2020) New satellite technology applied to monitoring of Antillean manatees (Trichechus manatus). Sirenews: Newsletter of the IUCN Sirenia Specialist Group, 71, 36-37.

Castelblanco-Martínez, D.N., Padilla-Saldívar, J., Hernández-Arana, H.A., Slone, D.H., Reid, J.P. \& Morales-Vela, B. (2012) Movement patterns of Antillean manatees in Chetumal Bay (Mexico) and coastal Belize: a challenge for regional conservation. Marine Mammal Science, 29, 1-17.

Da Silva, K.G., Paludo, D., De Oliveira, E.M., De Lima, R.P. \& SoAVInSKi, R.J. (2011) Distribuição e ocorrência do peixe-boi marinho (Trichechus manatus) no estuário do rio Mamanguape, Paraíba, Brasil. Natural Resources, Aquidabã, 1, 5-14.

de Lima, R.P., de Alvite, C.M.C., Reid, J.P. \& Bombassaro Júnior, A. (2012) Distribuição espacial e temporal de peixes-bois 
(Trichechus manatus) reintroduzidos no litoral nordeste do Brasil. Natural Resources, Aquidabã, 2, 63-80.

de Lima, R.P., de Alvite, C.M.C. \& Vergara-Parente, J.E. (2007) Protocolo de Reintrodução de Peixes-Bois-Marinhos no Brasil. 2nd edition. IBAMA, São Luis, Brazil.

De Lima, R.P. \& de Passavante, J.Z.O. (2013) Avaliação da primeira década (1994-2004) das reintroduções de peixes-bois marinhos (Trichechus manatus) no nordeste do Brasil. Natural Resources, Aquidabã, 3, 26-41.

de Lima, R.P., Paludo, D., Soavinski, R.J., Da Silva, K.G. \& de Oliveira, E.M.A. (2011) Levantamento da distribuição, ocorrência e status de conservação do peixe-boi marinho (Trichechus manatus, Linnaeus, 1758) no litoral nordeste do Brasil. Natural Resources, $1,41-57$.

Deutsch, C.J., Reid, J.P., Bonde, R.K., Easton, D.E., Kochman, H.I. \& O’SHEA, T.J. (2003) Seasonal movements, migratory behavior, and site fidelity of West Indian manatees along the Atlantic coast of the United States. Wildlife Monographs, 67, 1-77.

Deutsch, C.J., Self-Sullivan, C. \& Mignucci-Giannonni, A. (2008) Trichechus manatus. In The IUCN Red List of Threatened Species 2008. dx.doi.org/10.2305/IUCN.UK.2008.RLTS.T22103A93 56917.en [accessed 12 August 2020].

Edwards, H.H., Martin, J., Deutsch, C.J., Muller, R.G., Koslovsky, S.M., Smith, A.J. \& Barlas, M.E. (2016) Influence of manatees' diving on their risk of collision with watercraft. PLOS ONE, 11, eo151450.

Favero, I.T., Favero, G.E., Choi-Lima, K.F., Souza-alves, P. \& LE, L. (2020) Effects of freshwater limitation on distribution patterns and habitat use of the West Indian manatee, Trichechus manatus, in the northern Brazilian coast. Aquatic Conservation: Marine and Freshwater Ecosystems, 30, 1665-1673.

Flamm, R.O., Weigle, B.L., Wright, I.E., Ross, M. \& Aglietti, S. (2005) Estimation of manatee (Trichechus manatus latirostris) places and movement corridors using telemetry data. Ecological Applications, 15, 1415-1426.

ICMBIO (2011) Plano de Ação Nacional para a Conservação dos Sirênios. Instituto Chico Mendes, Brasilia, Brazil.

ICMBIO (2018) Livro Vermelho da Fauna Brasileira Ameaçada de Extinção: Volume II - Mamíferos. 1st edition. Instituto Chico Mendes, Brasilia, Brazil.

Lefebvre, L.W., Marmontel, M., Reid, J.P., Rathbun, G.B. \& Domning, D.P. (2001) Status and biogeography of the West Indian manatee. In Biogeography of the West Indies: Patterns and Perspectives (eds C.A. Woods \& F.E. Sergile), pp. 425-474. CRC Press, Boca Raton, USA.

Luna, F.D.O., De Lima, R.P., De Araújo, J.P., Zanon, J. \& Passavante, D.O. (2008) Status de conservação do peixe-boi marinho (Trichechus manatus manatus Linnaeus, 1758) no Brasil. Revista Brasileira de Zoociências, 10, 145-153.

Medeiros, I.D.S., Rebelo, V.A., Dos Santos, S.S., Menezes, R., Almeida, N.V., Messias, L.M. et al. (2021) Spatiotemporal dynamics of mangrove forest and association with strandings of Antillean manatee (Trichechus manatus) calves in Paraíba, Brazil. Journal of the Marine Biological Association of the United Kingdom, 101, 503-510.

Meirelles, A.C.O. (2008) Mortality of the Antillean manatee, Trichechus manatus manatus, in Ceará State, north-eastern Brazil. Journal of the Marine Biological Association of the United Kingdom, $88,1133-1137$.

Normande, I.C., Attademo, F.L.N., Luna, F.O., Borges, J.C.G., Lima, R.P., Sommer, I.B. et al. (2019) Reintroduction program of Antillean manatees (Trichechus manatus) in Brazil. First International Workshop on Marine Mammal Conservation Translocations. 5-6 December 2019, Barcelona, Spain.

Normande, I.C., Luna, F.D.O., Malhado, A.C.M., Borges, J.C.G., Viana Junior, P.C., Attademo, F.L.N. \& Ladle, R.J. (2015) Eighteen years of Antillean manatee Trichechus manatus manatus releases in Brazil: lessons learnt. Oryx, 49, 338-344.

Normande, I.C., Malhado, A.C.M., Reid, J., Viana, P.C., Savaget, P.V.S., Correia, R.A. et al. (2016) Post-release monitoring of Antillean manatees: an assessment of the Brazilian rehabilitation and release programme. Animal Conservation, 19, 235-246.

Paludo, D. \& Langguth, A. (2002) Use of space and temporal distribution of Trichechus manatus manatus Linnaeus in the region of Sagi, Rio Grande do Norte State, Brazil (Sirenia, Trichechidae). Revista Brasileira de Zoologia, 19, 205-215.

Parente, C.L., Vergara-Parente, J.E. \& Lima, R.P. (2004) Strandings of Antillean manatees, Trichechus manatus manatus, in northeastern Brazil. Latin American Journal of Aquatic Mammals, 3, 69-75.

QGIS Development Team (2019) QGIS: A Free and Open Source Geographic Information System. qgis.org/en/site [accessed 25 May 2020].

R Core Team (2018) R: A Language and Environment for Statistical Computing. r-project.org [accessed 17 February 2020].

Reynolds, J.E., Powell, J.A. \& Taylor, C.R. (2009) Manatees: Trichechus manatus, T. senegalensis, and T. inunguis. In Encyclopedia of Marine Mammals (eds W.F. Perrin, B. Würsig \& J.G.M. Thewissen), pp. 682-691. 2nd edition. Academic Press, Amsterdam, The Netherlands.

Ross, M. (2007) Seasonal and diel patterns of manatee habitat use. MSc Thesis. University of Central Florida, Orlando, USA. stars.library.ucf.edu/etd/3325 [accessed 6 October 2021].

St Aubin, D.J. \& Lounsbury, V. (1990) Oil effects on manatees: evaluating the risks. In Sea Mammals and Oil: Confronting the Risks (eds J.R. Geraci \& D.J. St Aubin), pp. 241-251. Academic Press, San Diego, USA.

White, J.R. \& FrAnCis-Floyd, R. (1990) Marine biology and medicine. In CRC Handbook of Marine Mammal Medicine: Health, Disease and Rehabilitation (ed. L.A. Dierauf), pp. 601-623. CRC Press, Boca Raton, USA. 